\title{
OUTLINE OF THE QING LAW
}

\begin{abstract}
A b stract. This paper attempts to sketch an outline of the Chinese law during the Qing, the last dynasty to rule over China. It also depicts the moral and philosophical basis on which the traditional Chinese legal system had been built long time before the Machu Emperors came to power. The paper also postulates that that it is culture rather than nature that determines law and morality, and the idea of universal ethics is but a utopia. There are some stark differences between western law and its Chinese counterpart. Some provisions of the Qing Code can be surprising for us today, although they become easy to comprehend, when looked at more closely. From the Chinese perspective, the western law can be called "modern" for it has been adopted by modern China since the early 20th century. The paper proposes an answer as to why China had to forsake its legal tradition and adopt the western continental law in its stead.
\end{abstract}

\section{0 . THE SPIRIT OF THE TRADITIONAL CHINESE LAW}

\section{INTRODUCTION}

The decline and fall of the Qing Empire seemed inevitable if one takes into consideration the military and economic prowess of the West as opposed to the sorry state of the Machu-governed China. In China, it was by far and away more virtuous to be a loyal bureaucrat than a successful merchant or engineer, and where the canons they cast were equally fatal to the enemy as to the soldiers who ignited the fuse. We should bear in mind, however, that at the end of the 19th century, a significant number of the Chinese literati struggled to bridge up the civilization gap that had grown between China and the West, so in science and technology as in the legal system, although the latter came later and was cut short by the republican revolution

JAROSŁAW ZAWADZKI - Department of Sinology on Faculty of Humanities at John Paul II Catholic University of Lublin; address for correspondence_e-mail: smallwall@gmail.com 
of 1911, which eventually sealed the weary eyes of the Machu rule in everlasting slumber and made the Chinese adopt western continental law.

In order to understand the reasons and the very essence of the attempted legal reforms under the Qing and the final conversion to the western law, it is more than necessary to have an idea, at least a rough one, as to what the traditional Chinese law was actually like, and in what ways it differed from the western legal traditions, which were, to a greater or lesser extent, the guiding rods for the Qing reformers. This is, to a great extent, what this paper is about.

THE THREE GUIDING PRINCIPLES AND THE FIVE UNCHANGING VIRTUES (SAN GANG WU CHANG)

Legal precepts and specific regulations are not innate in human beings. Although the term "natural law" is widely ("wildly" would be a more accurate word) used both by lawyers and philosophers, it is very misleading. It is neither the case that:

1) $[\ldots]$ the law of nature stems from the God's will, which has been revealed and is reflected in our conscience. ${ }^{1}$

nor that:

2) The law of nature is also universal, rational and secular; whereas the knowledge of good and evil is an objective one. ${ }^{2}$

It suffices to take but a shallow glance at the traditional Chinese law to realize, that such an interpretation is more of a wishful thinking than anything else. ${ }^{3}$ Law of any community that there exists (and especially the law of the ancient past) is based, to a significant degree, on morality, which, in its course, stems from the philosophy and/or religion that prevail within the given community, and is eventually sanctioned and imposed on every individual by the sovereign ruler. We shall see below that some provisions of the

\footnotetext{
${ }^{1}$ STEFAn Korycki (ed.), Zarys prawa [Outline of Law], Warszawa: Wydawnictwo Prawnicze "LexisNexis," 2007, p. 18. This and subsequent translations by the author.

2 Tatiana Chauvin, Tomasz Stawecki, and Piotr Winczorek, Wstęp do prawoznawstwa [An Introduction to Legal Studies], Warszawa: C.H. Beck, 2011, p. 7.

${ }^{3}$ Even in our western tradition, the disputes concerning abortion or euthanasia are a case in point, as there is no agreement as to whether these should be legal or not. So, the God-given regulation that reads: "Thou shalt not kill" is not reflected in everyone's conscience and thus not objective.
} 
Chinese law or the moral roots from which they stem are contrary to the European ethics or legal ideas. ${ }^{4}$ Which, of course, does not preclude similarities on the moral ground. ${ }^{5}$

The law of the Chinese Empire drew heavily on the concepts of Chinese philosophy, mainly Confucianism, although one of the most important precepts of Chinese morality and law can be found in the writings of the socalled legalist school ( $f a$ jia). In the book entitled Han Fei Zi (Master Fei of Han), attributed to Fei of Han, but written by many authors of a like mind, we encounter the idea of the "three guiding principles (san gang)" espoused also by Confucianism:

3) I have heard people say: "Servants serve the master, sons serve the father, and wives serve their husbands. If these three [rules] are obeyed, [then] the world is well-governed; if these three [rules] are rebelled against, [then] the world is a shambles."

The "three guiding principles" became, in the Confucian lore, almost inseparable from the "five unchanging virtues (wu chang)": benevolence (ren), righteousness (yi), etiquette (li), wisdom (zhi) and trust (xin). The idea of benevolence is very similar to the second great commandment of Jesus Christ: "Thou shalt love thy neighbour as thyself." In the Lun Yu (Analects), Confucius says:

4) Do not impose on others that which you do not wish for yourself. ${ }^{8}$

Righteousness should not be confused with justice, as justice is objective and as such irreconcilable with the Confucian set of mind, which is imbued with what is moral, customary and proper (i.e. what a sage deems to be proper) in a given situation, irrespectively of any stipulations to the contrary. For example, in the Analects we read:

5) Duke She asked Confucius: "In my village there is an upright man. When his father had stolen a sheep, the son reported his father [to the authorities]." Confucius replied: "In my village uprightness is something [quite]

\footnotetext{
${ }^{4}$ Cf. citations: 6), 7), 14), 15), 21).

${ }^{5} \mathrm{Cf}$. citation 5).

${ }^{6} \mathrm{Fu}$ Wuguang and Fu Yanyuan (eds.), Xin yi Han Fei $\mathrm{Zi}$ [Master Fei from Han again explained], Taipei: Sanmin Shuju, 1997, p. 750.

${ }^{7}$ Robert CARroll and Stephen Prickett (eds.), The Bible authorized King James version, Oxford: Oxford University Press, 1997, bk. St. Mathews 22:39.

${ }^{8}$ ZhANG Youchi (ed.), Si shu du ben [Four Books], Yonghe: Zhiyang, 1998, p. 199.
} 
different. Fathers cover up for their sons, and sons cover up for their fathers. This is what uprightness is all about."9

In the above passage we are able to notice that according to Confucius it is right to give false testimony in the court of law as long as the lie serves the interests of the family, i.e. satisfies the requirements of filial piety and parental love: both important tenets of Confucius' doctrine.

The etiquette (also translated as ceremonies) was the outer manifestation of all other virtues, so that those who did not possess the right qualities and simply did not know how to behave were only subject to the legal judgments and punishments that the law would inflict on them; when those who did posses the right virtues, simply did not commit any sin or crime. ${ }^{10}$ In the $L i$ $J i$ (Book of Etiquette) we find a passage that reads:

6) Etiquette does not descend to the common folk, punishment does not ascend to the high officials. ${ }^{11}$

Equality before the law was thus a heretic idea in ancient China.

Wisdom and trust were indispensable faculties of a Man of Honor or a Ruler (Jun $\mathrm{Zi}$ ). Only wisdom guaranteed ethical behavior and led to righteous judgments. Only trust in other person's loyalty (which was a manifestation of moral integrity) made benevolence needed and worthwhile:

7) If the Ruler is trustworthy, then the people dare not be impassionate. ${ }^{12}$

\section{THE THREE PATHS AND THE FOUR VIRTUES (SAN CONG SI DE)}

Female members of the traditional Chinese society were even more underprivileged than their counterparts in pre-modern Europe:

8) There are three paths that a woman rightly has. There is no way she can be on her own. Therefore, when not yet married, she must follow her father. When already married, she must follow her husband. And when her husband is dead, she must follow her sons. ${ }^{13}$

\footnotetext{
${ }^{9}$ Ibid., p. 219.

${ }^{10}$ In Chinese, we can use the same word for crime and sin: zui.

${ }^{11}$ WANG MeN'OU and WANG Yunwu (eds.), Li ji jin zhu jin yi [Book of Etiquette with modern commentary and translation], Taipei: Shangwu Yinshuguan, 1984, p. 43.

${ }^{12}$ Zhang Youchi (ed.), Si shu du ben, p. 219.

13 Ding Ding, "Yi li: sang fu" kao lun [Discussing "Rites and Ceremonies: Funeral"), Beijing: Shehui Kexue Wenxian Chubanshe, 2003, p. 148.
} 
It is obvious then that women were not supposed to take their lives in their own hands and were, for all practical purposes, degraded to the position of slaves. In addition to the "three paths" stated above, women were also obliged to observe the "four virtues":

9) Courtesans have acquired the art of education for women, and teach lesser concubines proper behavior, speech manners, proper looks, and meritable work; each of them must also control their relatives and give herself over to the king when the time is ripe. ${ }^{14}$

These had been at first meant for women in the king's harem, but eventually it became the sine qua non of a well-bred girl from a good family.

A married woman moved into the house of her husband. She could be expelled on the grounds of a specified set of misbehaviors:

10) If she obeys not your parents-bid her go, if she has no son-bid her go, if she is lascivious-bid her go, if she is jealous - bid her go, if she has a nasty disease - bid her go, if she speaks too much—bid her go, if she steals -bid her go. ${ }^{15}$

There were nonetheless three cases that prevented the husband from sending his wife off:

11) If she has no place to return to - let her stay, if she was in mourning for three years-let her stay, if you were poor before [marriage] and now you are rich—let her stay. ${ }^{16}$

The three years of mourning mentioned above pertain to the mourning required, by Confucian morality, from the son and his wife after the death of one of his parents. Thus fulfilling a moral obligation strengthened woman's position in the family. Sending off a woman with no place to return to could result in her becoming a prostitute or thief, so the law stipulated against such expulsions in order to prevent disharmonious outcomes in the society.

${ }^{14}$ WANG YUNWU (ed.), Zhou li jin zhu jin yi [Ceremonies of Zhou with modern commentary and translation], Taipei: Shangwu Yinshuguan, 1972, p. 76.

${ }^{15}$ Ho Che Wah, Chu Kwok Fan, and Fan Sin Piu (eds.), "Gu lie nü zhuan”-yu xian Qin Liang-Han dianji chongjian ziliao huibian, "Dadai li ji " yu xian Qin Liang-Han dianji chongjian ziliao huibian ["Old Biographies of Great Women"- a reconstructed compilation of canonical texts from the Qin and Two-Han periods, "Great Book of Respectable Etiquette"a reconstructed compilation of canonical texts from the Qin and Two-Han periods], Hong Kong: Chinese University Press, 2004, p. 58.

${ }^{16}$ Ibid., p. 241. 


\section{CRUEL PUNISHMENTS}

One might think that capital punishment would be the harshest penalty for a crime. The traditional Chinese law had, however, the means to deal with criminals in more horrible ways; death being but a part of the punishment.

If you were sentenced to death, you could be torn apart by four horses running each in a different direction, beaten or chopped into mincemeat or your head, having been disjoined from the corpus, would be then displayed on a stick for all to see. The cruelest way to die, though, was the following: first they would brand your face, next they would cut off your nose, then they would severe your toes and, having flogged you to death with a bamboo strip, they would put you head on pole and show it around the town. That was the so called "full-five punishment" ( $j u$ wu xing). There was also a way to get rid of not only the culprit but also his relatives (wife, children and/or parents): it was known as "clan slaughter" $(z u z h u)$, of which there were several kinds different in that who of your relatives should share you sorry lot. There were, of course, lighter penalties like forced labor, flogging (not to death) or banishment to the borderlands. ${ }^{17}$

\section{MANDATE OF HEAVEN}

The ancient legal system is often called the "rule of man" (ren zhi) as opposed to the western notion of the "rule of law" ( $f a z h i)$. It was a man (both the Emperor and to a significant extent also local mandarins) who made juristic decisions, which now and then were vaguely or not at all based on the promulgated regulations. The Emperor could invalidate any of his previous edicts with another one ad hoc. ${ }^{18}$ Mandarins could come up with new stipulations on the spur of a moment if they felt like it, only to forget them when they were no longer useful.

The ruler was accepted and revered by the common people as long as he held the so called "Mandate of Heaven" (tian ming). His authority would last

\footnotetext{
${ }^{17}$ Ye Xiaoxin, Zhongguo Fazhi Shi [A History of Chinese Legal System], Beijing: Peking University Press, 2000, pp. 51-53.

${ }^{18}$ Such incidents are not merely a thing of the past, which has been proved by Mark Kitto's in an article of his that reads: "I was once a plaintiff in the Beijing High Court. I was told, off the record, that I had won my case. While my lawyer was on his way to collect the decision the judge received a telephone call. The decision was reversed." Cf. MARK KitTO, You'll never be Chinese, http://www.prospectmagazine.co.uk/politics/mark-kitto-youll-never-be-chinese-leaving-china, (accessed 12.09.2012).
} 
as long as he held the Mandate. The indication that the ruler had been deprived of the Mandate was his loss of actual authority and power. When a rebellion broke out, and a common highwayman seized the throne (as it happened not once), the Mandate of Heaven would automatically be assigned to the roughneck provided he had not been outmatched by some other claimant.

\section{QING LAW}

\section{INTRODUCTION}

Long before the Manchu tribes conquered the Ming Empire, they had already come into contact with the Chinese law and recognized its usefulness. In 1467, nearly two centuries before the conquest, the first legal code was promulgated in the Manchu state. The code, known as Da Qing Lü Ji Jie $\mathrm{Fu}$ Li (Compilation and Explication of the Laws of the Great Qing, with bylaws), was an almost perfect copy of its Ming counterpart: three articles were deleted and one was added. ${ }^{19}$ After the conquest of China, this code was reviewed and, in 1740, came in effect as Da Qing Lü Li (Laws and Bylaws of the Great Qing). It was not however a stable set of laws nor was meant to be. In 1746, Qianlong Emperor declared that the code should undergo minor modifications every five years, and major refinements every ten years. And so the original 1049 bylaws, swelled to 1892 in the ninth year of Guangxu's rule, i.e. $1883 .^{20}$ The so called "bylaws" or "substatues", as Bodde calls them, ${ }^{21}$ were usually Emperors' decrees.

Traditional Chinese jurisprudence had no notion of civil, criminal or administrative branches of law as such. So, it goes without saying that there was no clear distinction between public and private law either. The legal system was a policing device to keep the society peacefully in place. It would be a mistake, however, to claim that the law dealt only with such offenses like breaches of peace, robbery or any other sort of violence, that is all that which in modern jurisprudence we call criminal law. China being a populous country could not go without sales contracts, loans or regulations on marriages and

\footnotetext{
${ }^{19}$ ZHU Yong, Zhongguo Fazhi Shi [A History of Chinese Legal System], Beijing: Falü Chubanshe, 2007, p. 291.

${ }^{20}$ Ibid.

${ }^{21}$ Derk Bodde and Clarence Morris, Law in Imperial China, Philadelphia: University of Pennsylvania Press, 1973, p. 63.
} 
inheritance-i.e. civil law. It would be a shambles, too, if there were no regulations on local authorities and their relations with the throne and the public - although an infringement of a civil law stipulation was mostly viewed as a crime (punished by flogging, imprisonment, etc), not as a tort (damages were provided for, occasionally, as an additional penalty though).

\section{THE QING CODE: LAwS AND BYLAwS OF THE GREAT QING ${ }^{22}$}

The core of the legal system was Da Qing Lü Li (Laws and Bylaws of the Great Qing), which consisted of seven sections: ${ }^{23}$

1. Regulations on Names and Measures

2. Regulations on Officials

3. Regulations on Families

4. Regulations on Ceremonies

5. Regulations on the Military

6. Regulations on Crimes

7. Regulations on Labor

\section{REGULATIONS ON NAMES AND MEASURES}

The first section of the first chapter enumerates the various punishments that awaited a malfeasant. For minor offenses there was flogging. The flogging was of two kinds: with a small bamboo strip or with a big bamboo strip. The number of blows the culprit received (i.e. the degree of the punishment) depended on the weight of the offense. Then there was imprisonment, which was always accompanied by flogging as well. The longest term was 3 years and it came with one hundred blows inflicted using a big bamboo strip. The fourth kind of punishment that there was consisted in banishment for the distance of 2000, 2500 or 3000 miles (one mile was about $576 \mathrm{~m}$ ), ${ }^{24}$ accompanied by one hundred blows with a big bamboo strip. The final and harshest penalty was of course capital punishment, which came in two flavors: stran-

\footnotetext{
${ }^{22}$ It is worth mentioning that the Qing code, as well as those of the preceding dynasties, were heavily influenced by the Tang Code of laws.

${ }^{23}$ Ma JiAnshi and Yang Yuchang (eds.), Da Qing Lü Li Tongkao Xiaozhu [Laws and Bylaws of the Great Qing Examined and Annotated), Beijing: Zhongguo Zhengfa Daxue Chubanshe, 1992 , p. 1.

${ }^{24}$ Endymion Wilkinson, Chinese History: A Manual, Cambridge: Harvard University Asia Center, 2000, pp. 237-238.
} 
gulation and decapitation. Death sentence could be however postponed in some cases, so that they take place in fall, ${ }^{25}$ that is after the harvest, which might imply that, at least in some areas, farmhands were in short supply during the summer crop season.

The penalty system drew heavily on the family discipline: virtually every offense or crime (although there was no legal distinction between those two) was punished by flogging. Except the death sentence, in case of which no flogging made much sense.

The second section defines ten atrocities:

1. Conspiring against the state (threatening the Gods of Earth and Grain ${ }^{26}$ ).

2. Plotting high treason (attempting to destroy ancestral temples, tombs and the royal palace).

3. Plotting insurgence (against one's own country with a hidden intention to serve a foreign state).

4. Atrocious misconduct (beating up or planning to murder one's elders in the family).

5. Lack of morals (killing three persons, not guilty of capital offense, in one family; or mutilating a live person in order to concoct poisons, pray to ghosts or inflict a curse)

6. Great disrespect (stealing things that belong to the Spirits or to the Emperor, taking advantage of the Emperor's coach or clothes, stealing or counterfeiting the Emperor's seal, preparing medicines for the Emperor without due compliance with the recipe or attaching a wrong label, disrespecting proscriptions on ingredients when preparing a meal for the Emperor and providing the Emperor with an unstable boat).

7. Lack of filial piety (accusing or abusing one's grandparents, parents, husband's grandparents or parents, moving to a different location or dividing wealth while grandparents or parents are still alive or lacking in due care for them, marrying, enjoying oneself or wearing auspicious clothes while in mourning for one's parents, refusing to mourn one's grandparents or parents or pretending to be in mourning)

8. Disharmony (killing, beating up, selling or accusing relatives who held specified relation ties to the offender).

9. Meanness (killing government officials or army commanders, marry-

\footnotetext{
${ }^{25}$ Ma JiAnShI and Yang YuChang, Da Qing Lü Li Tongkao Xiaozhu, pp. 191-192.

${ }^{26}$ The expression "Gods of Earth and Grain" stands for the authority and government of the state.
} 
ing again, enjoying oneself or wearing auspicious clothes while in mourning for one's husband).

10. Inner disorder (indulging in incest and the like). ${ }^{27}$

These being the most serious crimes in the Qing Empire, they were of two types: crimes against the family $(5,7,8,9,10)$ and crimes against the state $(1,2$, $3,4,6$ and partly 9), where the state could be thought of as a macro-family. They were a vivid manifestation of the fact that the empire had been built and was governed on the firm basis of Confucians precepts of hierarchy and power: homicide was differentiated not with respect to whether it was planned or accidental but with respect to the position the victim had held in the society.

Far from the modern idea of everyone being equal before the law, the Qing law stated overtly groups of people who were privileged in case of a standard legal proceeding against them or against specified relatives of theirs.

These groups were:

1. Specified relatives of the Emperor.

2. Those who had paid long service to the Emperor.

3. Those who had showed military prowess in defeating the enemy, conquering new land and establishing peace.

4. Those who had proved themselves to be wise, and whose conduct could be made into a law.

5. Those who had showed skill in leading the army and were most helpful to the Emperor.

6. Those who had proved themselves to be arduous in their tasks in the state administration.

7. Specified nobles.

8. Guest of the State. ${ }^{28}$

Whether they should be judged for a regular offense, was to be decided by the Emperor himself. A bylaw to this article also stated that they might not be manacled during the litigation. Had they however committed one of the ten atrocities (enumerated above), such concession would not be granted. ${ }^{29}$

A special variety of privilege was applicable to state officials. Had they committed a public offense (that is in the capacity of an officer) the penalty

\footnotetext{
${ }^{27}$ Ma JiAnShI and Yang Yuchang, Da Qing Lü Li Tongkao Xiaozhu, pp. 204-205.

${ }^{28}$ Ibid., p. 206.

${ }^{29}$ Ibid., p. 207.
} 
of flogging was to be substituted by a pecuniary fine, e.g. ten blows with a small bamboo strip were to be replaced with the forfeiture of one month's salary, whereas those who deserved one hundred blows should be degraded and transferred to a different post. Had the officer committed an offense as a private person, ten blows would cost him two months of salary, whereas 100 blows would mean absolute demotion and removal from the office. ${ }^{30}$

All the banner men, that is nomad people (largely Manchus) who had settled down within the borders of the Qing Empire, were not to suffer the penalty of banishment but pillory awaited them instead. ${ }^{31}$ As wives of the banished men were obliged to follow their husbands, it would mean removing a banner man and his family from the border areas in the north where they were living, which would subsequently pose a threat of depopulation in the sparsely populated border regions - a dangerous outcome for the safety of the state. That was probably why banner men held such a privilege.

In accordance with the Confucian virtue of filial piety (xiao), a transgressor who had been sentenced to death had the chance of getting a lighter sentence if he had needy parents or grandparents and no other male member of the family was able to support them. Similarly, when the sentence consisted in banishment and the criminal was the sole provider of his elders, he was to stay home and receive one hundred blows and pay a fine instead. ${ }^{32}$

Specified relatives were obliged by the law to cover for one another in court (bici dei xiangwei rongyin), ${ }^{33}$ which stood in accordance with the Confucius' words quoted in 6). This regulation pertained not only to the first degree relatives but also to such relations as wife's parents or grand-daughter's children, who were usually considered "outer family" if family at all.

The Qing Code provided for the legal principle (well know in western law), which states that a regulation on a specific subject matter overrides that which only concerns general matters (lex specialis derogat legi generali):

12) If an offense has its own name in a specific article, which differs from that which has been mentioned in the "Names and Measures", such an offense shall be judged by its specific regulation. ${ }^{34}$

\footnotetext{
${ }^{30}$ Ibid., pp. 215-216.

${ }^{31}$ Ibid., p. 217.

${ }^{32}$ Ibid., p. 240.

${ }^{33}$ Ibid., p. 294.

${ }^{34}$ Ibid., p. 296.
} 
On the other hand, the Qing Code had a provision that, by the western standards of jurisprudence, should be considered a prototypical example of unruliness:

13) All laws come into effect as of the day on which they have been issued. For offenses committed before that date, the new law shall be applied as well. ${ }^{35}$

This provision violates two western principles of law: Lex retro non agit (Law does not work backwards) ${ }^{36}$ and Nullum crimen, nulla poena sine praevia lege poenali (No punishment without a law authorizing it). ${ }^{37}$

\section{REGULATIONS ON OFFICIALS}

The second chapter deals with actions performed by state officials. It begins with regulations on hereditary posts, naming the primary successors and secondary successors in case the former are not among the living anymore, and it gives the penalties that shall be inflicted if the rules of inheritance are not strictly followed. There are also stipulations forbidding various misconducts that the officials might be prone to e.g. delay in taking up one's duties, tampering with the text of legal statutes or of the Emperor's edicts, collusion or quitting posts without permission. There are also provisions that oblige the clerks to study and understand the law-those clerks whose knowledge of the regulation turns out not to be sufficient are to be flogged. ${ }^{38}$

Another manifestation of the peculiarities of Confucian morality was the restriction on the use of Chinese characters that happened to be the names of the Emperor or his ancestors. This institution of the traditional Chinese law is usually referred to as "naming taboo" and was provided by the Qing Code in the following way:

14) Should one use, in a petition or a memorial to the throne, the Emperor's name or that of his ancestors, such person shall suffer eighty blows with a big bamboo strip. Should it happen in other types of texts, the punishment is forty blows with a small bamboo strip. Should someone use it as a name (not once by mistake but as a regular appellation), the penalty is one hundred blows with a big bamboo strip. Should one use the Emperor's name or that of his ancestors but in sound only, the characters used being

\footnotetext{
${ }^{35}$ Ibid., p. 304.

${ }^{36}$ Chauvin, STAWECKI, and WinczoreK, Wstęp do prawoznawstwa, p. 218.

${ }^{37}$ Bryan A. Garner, Black's Law Dictionary, 8th ed., St. Paul: Thomson West, 2004, p. 1098 b.

${ }^{38}$ Ma JiAnshi and YANG Yuchang, Da Qing Lü Li Tongkao Xiaozhu, p. 373.
} 
different, or where there are two characters only one of them being used, such a person should not be punished. ${ }^{39}$

The provision on the "naming taboo", harsh as it seems, was a trifle when compared with the sorry lot of those who broke this law but where tried for high treason instead: like Wang Xihou, who was sentenced to death (which was a due punishment for treason), ${ }^{40}$ his wealth confiscated, writings burnt, and close relatives taken to Beijing where two of his sons would be decapitated the following year (in fall, of course). ${ }^{41}$

\section{REGULATIONS ON FAMILIES}

The section on families, dealing mostly with civil law regulations ${ }^{42}$, is further divided into eight subsections:

1. Households

2. Land and housing

3. Marriage

4. Treasury

5. Taxes

6. Finance

7. Commerce $^{43}$

The economic domain was thus perceived as one of the facets of family life. There is then a striking and telling resemblance between this fact and the etymology of the English word "economy". The term "economy" has been

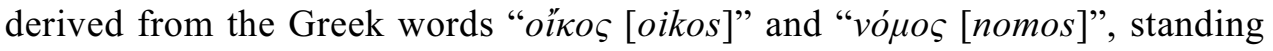
for "household" and "law" respectively, so that it basically means "law of the household." It might be an indication of the enormous significance of family as an economic unit in pre-modern societies both in Europe and in China.

The Qing law had strict regulations concerning everyday lives of the people. All inhabitants had to be registered with the local magistrate according to their profession and age. ${ }^{44}$

\footnotetext{
${ }^{39}$ Ibid., p. 382.

${ }^{40}$ Ibid., p. 675.

${ }^{41}$ Arthur William Hummel, Qingdai Mingren Zhuanlüe [Eminent Chinese of the Ch'ing Period], Vol. 2, Xining: Qinghai Renmin Chubanshe, 1990, p. 143.

${ }^{42}$ Although the stipulation quoted in 17) is of criminal nature.

${ }^{43}$ Ma JiAnShI and Yang YuChang, Da Qing Lü Li Tongkao Xiaozhu, p. 1.

${ }^{44}$ Ibid., p. 399.
} 
Adoption of children bearing surnames different from those of the adopting parties was proclaimed illegal unless the child to be adopted was less than three years of age. ${ }^{45}$

Judging by the following regulation:

15) Magistrate officials are obliged to provide for all widowers, widows, orphans as well as disabled or childless persons, who are destitute and have no relatives to support them, and who are not able to take care of themselves. Should they not do so, they shall be liable to 60 blows with a big bamboo strip. ${ }^{46}$

one could venture a new interpretation of the Qing Empire as a welfare state, which pays pensions to the poor and needing. Moreover, after a natural disaster like drought, flood or hail, the population that had suffered from the calamity was allowed to pay lower taxes or be exempt from them altogether. ${ }^{47}$ We must bear in mind, though, that local authorities were usually so far removed from the center and so remote from any other local government that they were, for all practical purposes, blissfully unsupervised, and the law would acquiesce to their purposes more often than the officials themselves would follow the law.

Some peculiarities of the Qing civil regulations may astound us not so much owing to the contents thereof, but because of the very need of having them in the Code. For example:

16) Whoever gains material profit (under a contract) from pawning or hiring out (for a while or trial period) his wife or concubine to be someone else's wife, shall (being her husband) receive 80 blows with a big bamboo strip. For pawning or hiring out a daughter he (the father) shall suffer 60 blows with a big bamboo strip. Women shall not be punished. ${ }^{48}$

It is not surprising that trading in women was illegal; what boggles the mind though is the meticulosity of this stipulation. It seems to suggest that such practices must have been quite often if not commonplace. One may wonder why would anyone want to give his wife or daughter to another man for pecuniary gain. One may wonder were it not for the fact that such misdemeanors might be but cover-up actions for running a bawdy house.

\footnotetext{
${ }^{45}$ Ibid., p. 409.

${ }^{46}$ Ibid., p. 419.

${ }^{47}$ Ibid., p. 425.

${ }^{48}$ Ibid., p. 444.
} 
Not only family life but also the economy of the country was heavily overburdened with state control. Laws and Bylaws of the Great Qing stipulated the maximum amount of monthly interest on a loan, which amounted to three "fractions" $" 49$ of the principal. ${ }^{50}$ Offering too high or too low a price was punishable like (or as if) embezzlement. ${ }^{51}$ Neither was it safe to peddle stuff of quality lower than declared:

17) If a commoner produces and sells inadequate and inferior tools or thin and spoiled silks that are too short or too tight, such person is liable to 50 whips with a small bamboo strip. ${ }^{52}$

As can be seen, no damages would be paid to the unlucky buyer of the inferior good. Caveat emptor, then.

\section{REGULATIONS ON CEREMONIES}

The fourth chapter of the Code consists mostly of laws on religious rituals, both public and private like funerals or festivals and it also includes related provisions like those concerning sacrilege and forbidden forms of worship. Christianity is not mentioned. It also regulates various matters concerned with the way people should clothe and what their housing should be according to the owners' social status.

\section{REgUlations ON THE MiLITARY}

The fifth chapter deals with the organization of the army (caring for the army horses and cattle is also included). It provides for offenses like employing troops without authorization, treason, desertion, selling out military equipment. It also criminalizes the possession of arms by civilians:

18) If a commoner privately possesses soldiers, horses, shields, fire guns, cannons or similar items worn by the banner men and which should be deemed restricted military equipment, he shall be liable to 80 blows with a big

\footnotetext{
${ }^{49}$ The Chinese term fen stands sometimes for one tenth, sometimes for one hundredth, and sometimes for one sixtieth. In relation to annual interest rates, it stands for one tenth. Cf. CHEN Fu and Nie Hongyin, Dangdai Hanyu cidian [Modern Chinese dictionary], Beijing: Beijing Normal University Publishing Group, 1993, p. 289.

${ }^{50}$ Ma JiAnshi and Yang YuChang, Da Qing Lü Li Tongkao Xiaozhu, p. 522.

${ }^{51}$ Ibid., p. 531.

${ }^{52}$ Ibid., p. 537.
} 
bamboo strip if he has only one piece. For each additional piece, the punishment shall be aggravated by one degree. ${ }^{53}$

It has provisions on the rules and restrictions related to entering the palace district, duties of the palace guards and court laborers.

This chapter also lays out the laws for mailing service of the empire, which clearly shows that the post offices were established mainly in order that the Emperor's edicts and other government dispatches might reach the local districts in a speedy and reliable manner.

It also deals with border protection not only in the political but also commercial sense:

19) Whoever takes horses, oxen, iron fit for military use (not yet made into weapons), copper coins, silk in bolts, silk scarves, silk floss for sale abroad or goes with them to sea, shall receive 100 blows with a big bamboo strip. ${ }^{54}$

\section{REGULATIONS ON CRIMES}

The sixth chapter lays out the core of the criminal and criminal processing laws of the Empire. It is divided into 11 sections:

1. Stealing

2. Human Life

3. Assault

4. Abusing

5. Litigation

6. Ill-gained profits

7. Frauds

8. Sexual misbehaviors

9. Various crimes

10. Detention

11. Sentencing

Producing and distributing books on magic and sorcery was punished by death or perpetual punishment. Mere possession of such books meant 100 blows with a big bamboo strip and three years of imprisonment. ${ }^{55}$

\footnotetext{
${ }^{53}$ Ibid, p. 596.

${ }^{54}$ Ibid, p. 617.

${ }^{55}$ Ibid, p. 662.
} 
Not all legal documents were meant for a commoner to have access to. Some imperial decrees and other legal documents produced by state bureaus (yamen) were closely guarded and their unauthorized possession was punishable:

20) Whoever steals an imperial decree (should it have no stamp, but be a copy only, it shall be regarded as an official document), shall be decapitated (no matter whether a principal or an accomplice).$^{56}$

21) Who steals an official document of a state bureau, shall receive 100 blows with a big bamboo strip and be branded. If someone evades it (encroaching upon assets, using bribes, etc)., he shall be punished most severely. If the matter concerns assets of a military unit, the offender shall be strangled (after imprisonment) (no matter whether a principal or an accomplice). ${ }^{57}$

Thus the Chinese legal tradition came up with an idea that you can actually steal the law, i.e. commit an offense by simply gaining access to a legal document. Not a top-secrete document, but just any piece of legislation. When compared with the Roman legal principle that states: ignorantia juris non excusat (ignorance of the law is no excuse), ${ }^{58}$ we can notice with surprise that it is not the ignorance of law that might be harmful in a specific place and time, but the very desire to acquire some knowledge of the law could turn out fatal. Of course, as most of the legal provisions in the Qing Code, it was not a nomad idea of the Machu tribal philosophy. The idea of stealing the law had been well established since centuries and was also stipulated in the Tang Code:

22) All who steal an imperial decree, are to be imprisoned for two years. Should it be a document produced by an office, the offenders should receive 100 blows with a big bamboo strip. ${ }^{59}$

The criminal law of the Qing Empire was harsh towards common banditry like robbery or assault:

23) All who commit a robbery involving the use of force but do not get the valuables, shall be sentenced for 100 blows with a big bamboo strip and a banishment of 3000 miles. However, if someone gets the (victim's) valuables, he shall be then decapitated no matter whether he has been a

\footnotetext{
${ }^{56}$ Ibid., p. 664.

${ }^{57}$ Ibid.

${ }^{58}$ GARNER, Black's Law Dictionary, p. 762b-763a.

${ }^{59}$ Zhangsun WujI, Tang Lü Shu Yi [Tang Law with comments and discussions], Beijing: Zhonghua Shuju Chuban, 1983, p. 350.
} 
principal or an accomplice. (Those who do not participate in the division of the booty, shall be punished as well. If someone does not carry out his ${ }^{60}$ intention and does not participate in the division of the booty, he shall be sentenced for 100 blows with a big bamboo strip and a banishment of 3000 miles. If accomplices do not carry out the intention and do not participate in the division of the booty, they shall be sentenced for 100 blows with a big bamboo strip). ${ }^{61}$

24) Who uses poison to intoxicate someone in order to acquire his valuables, is guilty of the same crime (but if the valuables are successfully acquired, everyone shall be decapitated). ${ }^{62}$

25) Robbers who have, at the same instant, detained and killed or harmed the victim, shall be all decapitated (after imprisonment) (no matter if they have gotten the booty or not. The expression "at the same instant" must be taken into consideration). ${ }^{63}$

Poisoning was a special case. In the case of a robbery involving the use of force the offenders were not punished with death if they neither took part in the illegal act themselves (e.g. planned or instigated only), nor participated in the division of the ill-gained property; whereas in the case of a poison-aided robbery, all culprits faced death if only the crime had been successfully accomplished, that is if the valuables hand been stolen, no matter if they participated in the booty or not. It may suggest that poisoning was much more prevalent in the Qing society than regular robbery with the use of force was, which should come as no surprise since commoners where not allowed to bear arms,${ }^{64}$ thus the feasibility of using force was significantly restrained.

Murders of the first degree were punishable by death. Accidental killings were usually punished less severely. A husband who caught her wife in the act of committing fornication, would not be punished for killing her and her bedmate, ${ }^{65}$ which again shows how significant were the social relations of the parties involved.

Rape was punishable by strangulation, whereas an extramarital intercourse between two consenting individuals would cost them 80 blows with

\footnotetext{
${ }^{60}$ I have chosen the traditionally used masculine possessive "his" for my translation, although the Chinese equivalent ( $q i)$ has no bearing on the sex of the individual, so it should be understood as "his or hers".

${ }^{61}$ Ma Jianshi and Yang Yuchang, Da Qing Lü Li Tongkao Xiaozhu, p. 683.

${ }^{62}$ Ibid.

${ }^{63}$ Ibid.

${ }^{64}$ Cf. citation 19)

${ }^{65}$ Ma Jianshi and Yang Yuchang, Da Qing Lü Li Tongkao Xiaozhu, p. 780.
} 
a big bamboo strip if the woman was unmarried, and 90 blows in the other case (unless the woman's husband had already lawfully killed them, as mentioned in the previous paragraph).

Quarreling within the precincts of the Imperial Palace was forbidden and punished by flogging. ${ }^{66}$ The punishment for hitting or verbally abusing a person depended, not surprisingly, on the relations (of office but also those of blood and marriage) between the parties involved. ${ }^{67}$

Accusing someone without revealing the accuser's own name was a fatal move, as it meant death by strangulation for the anonymous accuser, while the accused person would not be tried; even if the accusation happened to be true. ${ }^{68}$ This stipulation must have eradicated, to a great extent, the idea of suing a local potentate or official, as not many individuals would dare to accuse men of power.

Children and grandchildren who would not obey their parents or grandparents were punished by 100 blows with a big bamboo strip. ${ }^{69}$

It was not allowed to represent on stage Emperors and Empresses of all dynasties, sages and virtuous people of the past, loyal ministers, martyrs and divine beings. ${ }^{70}$ Probably for fear of a loss of face that they might suffer in case of a ridicule or calumny.

I $f$ those responsible for seizing and arresting offenders were not able to find the culprits within one month, they themselves were liable to corporal punishment (from ten to forty blows with a small bamboo strip depending on how many months it took them to finally catch the wanted runaways), and the local magistrate faced a forfeiture of one month's salary. ${ }^{71}$ This stipulation might lead to arresting (and eventually sentencing) an innocent individual, just so that the officers could go unpunished.

Prison guards were obliged to feed and clothe the prisoners if the latter had no supporting families (wu jia shu zhe). ${ }^{72}$ It was forbidden to send women to prison unless they were waiting for their own capital punishment or had committed adultery.

\footnotetext{
${ }^{66}$ Ibid., p. 825.

${ }^{67}$ Ibid., pp. 864-868.

${ }^{68}$ Ibid., p. 876.

${ }^{69}$ Ibid., p. 892.

${ }^{70}$ Ibid., p. 987.

${ }^{71}$ Ibid., p. 1022.

${ }^{72}$ Ibid., p. 1053. Cf. citation 16).

${ }^{73}$ Ibid., p. 1112.
} 


\section{REGULATIONS ON LABOR}

The seventh chapter has regulations on corvee labor and related works provided by the people in order to build state edifices and prevent flood. Corvee was, in effect, a different form of taxation.

\section{FINAL REMARKS}

It would be impossible to present and explain in detail all the intricacies of the Qing law in this paper (that would require a whole book), especially that in addition to the statue law (including edicts, decrees, laws and bylaws ${ }^{74}$ to name just the central government documents), there existed collections of judicial cases and rulings, resembling the English case law phenomenon. ${ }^{75}$

\section{REFORMS AND CHANGE}

\section{THE NEED FOR REFORMS}

The Code, being the most important statue in the whole Empire, did not provide much regulations in the sense of what we would call constitutional or administrative law. The laws concerning the rules of proceeding that the central government should follow are scarce and deal mostly with rituals and hierarchy more than with the actual way of "getting things done". The laws that deal with lower rank officers and local government (i.e. administrative law) mostly provide for:

- the punishment an officer should suffer if he abused his power or neglected his duties,

- the way the officers should be chosen or nominated,

- the structure and hierarchy of the government and its branches.

It was usually up to the local magistrate's discretion how to solve everyday administrative issues like giving an opinion on whether a bridge should be build in the village, where exactly it should be build, by whom how much would be spent on it (including bribes, of course).

\footnotetext{
${ }^{74}$ Of which only laws have been presented in this paper.

${ }^{75}$ For more details on the case law phenomenon see: DERK BODDE, Clarence Morris, Law in Imperial China, Philadelphia: University of Pennsylvania Press, 1973.
} 
No wonder then that the Qing were weak and submissive when facing such western powers like the Great Britain and newly united Germany and Japan $^{76}$ all of which had strong regimes based on steadfast rules. So, it only stood to reason that in the second half of the 19th century and in the beginning of the 20th century, after the Opium Wars (of which the last one ended in 1860), and even more fervently, after the treaty of Shimonoseki signed in 1895 , the Chinese literati were thinking of a way to drag their country out of this dismal condition.

It should be noted though that were not it for the fact that China had come into contact with western powers, there would be no reason to regard the Chinese legal system as inadequate and heading for a collapse. The system was steadfast and not about to fall to pieces due to its own inner weakness it was crumbling under the heavy foot of the western invaders reinforced with the philosophies of Enlightenment and buttressed up by the strengths that science and technology began to bestow on the "foreign devils."

\section{MODERNITY AT THE GATES}

Replacing the traditional Chinese legal system with a foreign one was not at all obvious to the first generation of reformers, the so called "foreign affairs party" (yangwu pai). They thought that what China needed to learn from the West was its technology, not its law. ${ }^{77}$ This however was a conceited misconception ever since the Treaty of Nerchinsk signed in 1689, when the international (i.e. European) law had been first forced upon China, when China had become a mere participant in the world politics and had lost its semi-divine position. However incidental the treaty had looked in the seventeenth century, when it had been signed, two hundred years later it turned out to have been but a starting point. China finally realized that the rules of the game had changed, and even the Middle Kingdom had now to adhere to the western international law (the very idea of which was unthinkable for the Chinese Emperors, who were used to receiving tribute from foreign states, not talk or compete with them on equal terms).

\footnotetext{
${ }^{76}$ Although Japan is situated to the east of China, its legal system had been, since the Meiji era, significantly westernized.

${ }^{77}$ FAn ZhongXin and Chen Jingliang (eds.), Zhongguo Fazhi Shi [A History of Chinese Legal System], Beijing: Peking University Press, 2010, p. 380.
} 
The information on the international law was scarce in China by the second half of the 19th century. In the year 1863, an American missionary William Alexander Parsons Martin translated Henry Wheaton's Elements of International Law into Chinese, and the Chinese gained a much wider access to the western law tradition.

In 1902 the Qing Empire and the United Kingdom signed a trade treaty: Zhong-Ying Xuyi Tong Shang Xing Chuan Tiaoyue (Sino-British Trade and Sailing Continuance Treaty), in which such a provision was to be found:

26) China deeply wishes to reorganize its laws, so that its laws be uniform with those of the western states. The United Kingdom is willing to provide utmost assistance in the realization of this task. ${ }^{78}$

Thus not only the Chinese were interested in China adopting the western law, it was on the Westerners' agenda, too.

Later on, the Chinese took to learning about the western law from Japanese sources, which were more easily accessible for them due to cultural and linguistic reasons. ${ }^{79}$ So, as the Japanese had modeled their new regime on that of the Prussian state, which had recently risen to power in Europe, the legal system of the Republic of China, which was about to be established in 1912, would also be based on the German law.

Thus it was through the need and necessity of international relations that China was "invaded" by the modern foreign legal ideas and institutions, which it had to come to grips with in order to deal with the world powers that knocked and rammed at the imperial and later republican door of a temporarily etherized dragon.

\section{BIBLIOGRAPHY}

Bodde, Derk, and Clarence Morris. Law in Imperial China. Philadelphia: University of Pennsylvania Press, 1973.

CARroll, Robert, and Stephen Prickett (eds.). The Bible authorized King James version. Oxford: Oxford University Press, 1997.

${ }^{78}$ Ibid., p. 393. (The English version of this provision and of the treaty's title is this paper's author's rendering of the Chinese text, i.e. not an official English text.)

${ }^{79}$ Although the languages of China and Japan are not genetically related, the Japanese writing system is partly based on Chinese script, which records meanings of the words rather than their sounds. 
Chauvin, Tatiana, Tomasz Stawecki, and Piotr WinczoreK. Wstęp do prawoznawstwa [An Introduction to Legal Studies]. Warszawa: C.H. Beck, 2011.

Chen Fu and Nie Hongyin. Dangdai Hanyu cidian [Modern Chinese Dictionary]. Beijing: Beijing Normal University Publishing Group, 1993.

DiNG DiNG. "Yi li: sang fu" kao lun [Discussing "Rites and Ceremonies: Funeral"]. Beijing: Shehui Kexue Wenxian Chubanshe, 2003.

Fan ZhongXin, Chen Jingliang (eds.). Zhongguo Fazhi Shi [A History of Chinese Legal System]. Beijing: Peking University Press, 2010.

Fu Wuguang, Fu Yanyuan (eds.). Xin yi Han Fei $\mathrm{Zi}$ [Master Fei from Han again explained]. Taipei: Sanmin Shuju, 1997.

Garner, Bryan A. Black's Law Dictionary, 8th ed. St. Paul: Thomson West, 2004.

Ho Che Wah, Chu Kwok Fan, Fan Sin PiU (eds.). "Gu lie nü zhuan ” - yu xian Qin Liang-Han dianji chongjian ziliao huibian, "Dadai li ji" yu xian Qin Liang-Han dianji chongjian ziliao huibian ["Old Biographies of Great Women"-a reconstructed compilation of canonical texts from the Qin and Two-Han periods, "Great Book of Respectable Etiquette"-a reconstructed compilation of canonical texts from the Qin and Two-Han periods]. Hong Kong: Chinese University Press, 2004.

Hummel, Arthur William. Qingdai Mingren Zhuanlüe [Eminent Chinese of the Ch'ing Period]. Vol. 2. Xining: Qinghai Renmin Chubanshe, 1990.

KitTo, MARK. You'll never be Chinese, http://www.prospectmagazine.co.uk/politics/mark-kittoyoull-never-be-chinese-leaving-china (accessed 12.09.2012).

Korycki, Stefan (ed.). Zarys prawa [Outline of Law]. Warszawa: Wydawnictwo Prawnicze "LexisNexis," 2007.

Ma Jianshi, YAng Yuchang (eds.). Da Qing Lü Li Tongkao Xiaozhu [Laws and Bylaws of the Great Qing Examined and Annotated]. Beijing: Zhongguo Zhengfa Daxue Chubanshe, 1992.

Wang Men'ou, Wang Yunwu (eds.). Li ji jin zhu jin yi [Book of Etiquette with modern commentary and translation]. Taipei: Shangwu Yinshuguan, 1984.

WANG YunwU (ed.). Zhou li jin zhu jin yi [Ceremonies of Zhou with modern commentary and translation]. Taipei: Shangwu Yinshuguan, 1972.

Wilkinson, Endymion. Chinese History: A Manual. Cambridge: Harvard University Asia Center, 2000.

Ye XiaOXin, Zhongguo Fazhi Shi [A History of Chinese Legal System]. Beijing: Peking University Press, 2000.

ZhANG Youchi (ed.). Si shu du ben [Four Books]. Yonghe: Zhiyang, 1998.

Zhangsun WujI. Tang Lü Shu Yi [Tang Law with comments and discussions]. Beijing: Zhonghua Shuju Chuban, 1983.

Zhu Yong. Zhongguo Fazhi Shi [A History of Chinese Legal System]. Beijing: Falü Chubanshe, 2007.

\section{ZARYS PRAWA QING}

Streszczenie

Artykuł jest próbą zarysu prawa chińskiego za czasów Qing, ostatniej dynastii rządzącej Chinami. Przedstawia on moralne i filozoficzne podstawy, na których został zbudowany tradycyjny chiński system prawny długo przed dojściem do władzy cesarzy Machu. Autor artykułu stwierdza również, że to kultura, a nie natura określa prawo i moralność, a idea etyki uniwersalnej jest utopią. Istnieją pewne różnice między prawem zachodnim a jego chińskim odpowiednikiem. Nie- 
które przepisy Kodeksu Qing mogą być dla nas dzisiaj zaskakujące, chociaż łatwo je zrozumieć, jeśli bliżej im się przyjrzeć. Z chińskiego punktu widzenia prawo zachodnioeuropejskie można nazwać „,nowoczesnym”, bo zostało przyjęte we współczesnych Chinach na początku XX wieku. $\mathrm{W}$ artykule pada propozycja odpowiedzi na pytanie, dlaczego Chiny zostały zmuszone do porzucenia swojej tradycji prawnej i przyjęcia w jej miejsce zachodniego prawa kontynentalnego.

Słowa kluczowe: prawo chińskie, dynastia Qing, prawo zachodnioeuropejskie, moralne i filozoficzne podstawy prawa.

Key words: Chinese law, Qing dynasty, Western law, moral and philosophical basis of law. 